\title{
Exploiting Knowledge of R/Avr Genes to Rapidly Clone a New LZ-NBS-LRR Family of Late Blight Resistance Genes from Potato Linkage Group IV
}

\author{
Anoma A. Lokossou, ${ }^{1}$ Tae-ho Park, ${ }^{1}$ Gert van Arkel, ${ }^{1}$ Marjon Arens, ${ }^{1}$ Carolien Ruyter-Spira, ${ }^{1}$ \\ Juan Morales, ${ }^{2,3}$ Steve C. Whisson, ${ }^{3}$ Paul R. J. Birch, ${ }^{2,3}$ Richard G. F. Visser, ${ }^{1}$ Evert Jacobsen, ${ }^{1}$ and \\ Edwin A. G. van der Vossen ${ }^{1}$ \\ ${ }^{1}$ Wageningen UR Plant Breeding, P.O. Box 386, 6700 AJ Wageningen, the Netherlands; ${ }^{2}$ Division of Plant Sciences, \\ University of Dundee (at Scottish Crop Research Institute), Errol Road, and ${ }^{3}$ Plant Pathology Programme, \\ Scottish Crop Research Institute, Invergowrie, Dundee DD2 5DA, U.K.
}

Submitted 18 December 2008. Accepted 13 February 2009.

In addition to the resistance to Phytophthora infestans (Rpi) genes Rpi-blb1 and Rpi-blb2, Solanum bulbocastanum appears to harbor $R$ pi-blb3 located at a major late blight resistance locus on LG IV, which also harbors $R$ pi-abpt, $R 2$, R2-like, and Rpi-mcd1 in other Solanum spp. Here, we report the cloning and functional analyses of four Rpi genes, using a map-based cloning approach, allele-mining strategy, Gateway technology, and transient complementation assays in Nicotiana benthamiana. Rpi-blb3, Rpi-abpt, R2, and $R 2$-like contain all signature sequences characteristic of leucine zipper nucleotide binding site leucine-rich repeat (LZ-NBS-LRR) proteins, and share amino-acid sequences 34.9\% similar to RPP13 from Arabidopsis thaliana. The LRR domains of all four Rpi proteins are highly homologous whereas $L Z$ and NBS domains are more polymorphic, those of $\mathrm{R} 2$ being the most divergent. Clear blocks of sequence affiliation between the four functional resistance proteins and those encoded by additional Rpi-blb3 gene homologs suggest exchange of LZ, NBS, and LRR domains, underlining the modular nature of these proteins. All four Rpi genes recognize the recently identified RXLR effector PiAVR2.

The potato (Solanum tuberosum) ranks as the world's third most important food crop after wheat and rice. Compared with these other staple crops, a greater proportion of the potato crop is edible and a higher yield per hectare is achieved, which, combined with its high nutritional value, underlines its importance and explains ongoing increases in global potato production. The most significant threat to potato production worldwide is the late blight disease, caused by the oomycete pathogen Phytophthora infestans, which destroys leaves, stems, and

Current address for T.-h. Park: Brassica Genomics Teams, National Institute of Agricultural Biotechnology, Suwon 441-707, Republic of Korea.

Corresponding author: R. G. F. Visser; Telephone: +31 317 482836; Fax: +31317 483457; E-mail: Richard.Visser@wur.nl

Current address of E. A. G. van der Vossen: Keygene N.V., Agro Business Park 90, 6708 PW Wageningen, The Netherlands.

* The $e$-Xtra logo stands for "electronic extra" and indicates that three supplementary tables and three supplementary figures are published online. tubers. Current disease control relies on multiple (up to 20) fungicide applications per season (Hanson et al. 2007) and costs associated with chemical control amount to $€ 5$ billion globally per year (Whisson et al. 2001). Such pesticide inputs are both environmentally and economically undesirable and have a negative impact on the sustainability of potato production. Host resistance is a more environmentally benign means of restricting late blight infection but the success of this management practices hinges on effective and durable host resistance and an understanding of the pathogen population.

Early in the 20th century, the potential of the wild Mexican hexaploid species $S$. demissum was recognized for conferring extreme levels of late blight resistance, and hybrids with $S$. tuberosum were generated. Subsequently, 11 major dominant resistance $(R)$ genes were identified and introgressed into potato cultivars (Malcolmson 1969; Malcolmson and Black 1966; Müller and Black 1952) However, deployment of these single genes did not provide durable resistance due to the rapidly changing populations of $P$. infestans. As an alternative approach, breeders started to select for quantitative "field" resistance using races of $P$. infestans that were compatible with the $R$ genes present in their breeding material (Black 1970; Toxopeus 1964). Despite considerable progress in genetic analysis of quantitative resistance to late blight using molecular markers (Gebhardt and Valkonen 2001; Simko 2002), under long day conditions, breeders have achieved little progress, the major drawbacks being tetrasomic inheritance of potato and the strong linkage between foliage resistance and late foliage maturity (Bradshaw et al. 2004; Oberhagemann et al. 1999; Visker et al. 2003). Therefore, it is anticipated that breeding for late blight resistance in potato, aimed at substantially contributing to disease management, requires the deployment of major resistance to $P$. infestans (Rpi) genes. Recent germplasm screens are revealing a wealth of Rpi genes in wild Solanum spp. and the challenge now is how to select, judiciously combine, and deploy sets of Rpi genes that can confer durable late blight resistance in modern potato cultivars.

Key to durable exploitation of Rpi genes is also a better understanding of their interactions with effectors from $P$. infestans. All microbes trigger immune responses in plants via host receptor-mediated recognition of pathogen-associated molecular patterns (PAMPs). Such PAMP-triggered immunity (PTI) can be suppressed by secretion of effectors which act either outside 
or inside host cells and reprogram host metabolism to promote effector-triggered susceptibility (ETS). When a successful pathogen has suppressed PTI, the products of plant $R$ genes, as a second "layer" of defense, can directly or indirectly detect effectors (termed avirulence [AVR] proteins). $\mathrm{R}$ proteins subsequently activate resistance responses (effector-triggered immunity $[\mathrm{ETI}])$, often including programmed cell death during the hypersensitive response (HR) (Jones and Dangl 2006). The ability of a pathogen to evade recognition in the $R$-gene-forAvr-gene concept (Flor 1971) can be explained by an evolutionary "arms race" (Bergelson et al. 2001; Holub 2001). The generation, through mutation, and selection of $A V R$ alleles that evade recognition is matched by strong selection pressure for $R$ gene alleles that retain recognition. This is particularly evident in the ATR1-RPP1 and ATR13-RPP13 interaction in the Hyaloperonospora arabidopsidis (formerly $H$. parasitica)Arabidopsis pathosystem, where considerable allelic diversity has been revealed by studying natural host and pathogen populations (Allen et al. 2008; Rehmany et al. 2005). In naturally co-evolving $P$. infestans-potato populations, similar high levels of allelic diversity are expected to be observed. So far, studies of the PiAVR3a-R3a interaction reveal diversifying selection for both genes (Amstrong et al. 2005; Huang et al. 2005). Recently, several oomycete $A V R$ genes were identified (Allen et al. 2004; Armstrong et al. 2005; Rehmany et al. 2005; Shan et al. 2004; Vleeshouwers et al. 2008). Although each of the AVR proteins is distinct at the level of primary sequence similarity, they all share a secretion signal peptide followed by the motif RXLR and an acidic region, often ending in the sequence EER (Birch et al. 2008a and b; Whisson et al. 2007). The RXLR-EER region is required for translocation of PiAVR3a, following its secretion from $P$. infestans haustoria, to the inside of host plant cells (Whisson et al. 2007). Translocation of RXLR-containing proteins inside the plant cell is consistent with their recognition by host nucleotide binding site leucine-rich repeat (NBS-LRR) resistance proteins (Birch et al. 2006). Because all oomycete AVR proteins identified to date have the RXLR motif, it provides a signature to identify AVR candidates from the $P$. infestans genome. Future knowledge of RXLR effectors diversity and their survey in $P$. infestans population could predict the lifespan of Rpi genes in specific areas.

Conventional introgression of resistance often involves interspecific crosses and repeated backcrosses with cultivated potato, which is a very slow and inefficient process. Currently, Rpi genes of natural origin, so-called cisgenes (Jacobsen and Schouten 2007; Schouten and Jacobsen 2008), can be introduced using marker-free transformation systems leading to cisgenic plants with only the genes of interest and without linkage drag of other genes from the wild species or from antibiotic resistance genes normally present at the T-DNA (de Vetten et al. 2003; Schaart et al. 2004; Yu et al. 2006). To date, six $R p i$ genes have been reported: $R 1$ and $R 3 a$ from $S$. demissum (Ballvora et al. 2002; Huang et al. 2005), RB/Rpi-blb1 and Rpi-blb2 from S. bulbocastanum (Song et al. 2003; van der Vossen et al. 2003, 2005), and Rpi-stol and Rpi-ptal from S. stoloniferum and $S$. papita, respectively (Vleeshouwers et al. 2008). All belong to the NBS-LRR class of plant R proteins, which are thought to be cytoplasmic (van der Biezen and Jones 1998). Various loci are reported to contain Rpi genes on linkage group (LG) VII (Kuhl and Hanneman 2001), LG IX (Sliwka et al. 2006; Smilde and Brigneti 2005), LG X (Ewing and Simko 2000; Rauscher et al. 2006), and LG XI (Bradshaw et al. 2006; Huang et al. 2004, 2005).

Here, we describe the cloning and functional characterization of Rpi-blb3, Rpi-abpt, R2, and R2-like from the major late blight resistance locus on LG IV of potato (Li et al. 1998; Park et al. 2005a, b, and c). Upon map-based cloning of Rpi-blb3, an efficient candidate gene allele-mining approach in combination with transient complementation in the heterologous Nicotiana benthamiana "model" system led to the rapid cloning of the other three genes. All four Rpi genes code for proteins of the NBS-LRR class of R proteins. Interestingly, with respect to known functional $\mathrm{R}$ proteins, they share the highest similarity (34.9\% amino acids) with RPP13 from Arabidopsis thaliana (Bittner-Eddy et al. 2000), which confers resistance to the oomycete $H$. arabidopsidis. Despite apparent differences between the four functional R proteins, all four induce an HR upon coexpression with the $P$. infestans-derived RxLR effector PiAVR2 (E. Gilroy, personal communication) in N. benthamiana leaves, indicating that they recognize the same effector protein.

\section{RESULTS}

\section{Cloning of Rpi-blb3 and Rpi-abpt.}

In order to clone Rpi-blb3 and Rpi-abpt, two bacterial artificial chromosome (BAC) libraries were constructed using DNA derived from the resistant clones Blb99-256-3 and 707TG11-1, respectively. Approximately 74,000 clones with an average insert size of $85 \mathrm{~kb}$, corresponding to eight genome equivalents, were obtained for each library. These libraries were screened initially with sequence-characterized amplified region marker Th21, which cosegregated with resistance in mapping populations of 1,396 and 1,383 F1 progeny plants (Park et al. 2005a). In this way, BAC clones Blb22 and TG9, respectively, were identified (Fig. 1A and 1B). By sequencing the ends of these two BACs, new markers were developed which were used to define the genetic intervals of the $R$ loci more precisely and to rescreen the BAC libraries to identify clones that overlapped with the initial BAC clones. In this way, the Rpi-blb3 locus was delimited to a 0.1-centimorgan (cM) interval (EAAC/MAAC_99- Blb25-T; 2/1,396 recombinants) that is physically spanned by the two partially overlapping BAC clones Blb22 and Blb25 (Fig. 1A). In the case of the Rpi-abpt locus, the partially overlapping BAC clones TG9 and TG77 were identified. One end of the contig cosegregated with resistance (TG77-S) while the other mapped $0.1 \mathrm{cM}$ proximal to Rpi-abpt (TG9-S) (Fig. 1B).

To gain insight into the molecular structure of the $R$ loci under study, BAC clones Blb22 and TG9 were sequenced to $6 \mathrm{x}$ coverage. This revealed that clone Blb22 did not contain any $R$ gene homologues (RGH) whereas clone TG9 contained two $\mathrm{RGH}$, which shared significant similarity to RGH present in the sequenced tomato BAC clone AF411807L (Van der Hoeven et al. 2002) (Fig. 1). BAC clones Blb25 and TG77 were subsequently screened for the presence of RGH-specific sequences through polymerase chain reaction (PCR) analysis using the primers 4-PLOOP-F and 4-GLPL-R (Table 1), which were designed by aligning the RGH sequences of clone AF411807L with those present on BAC clone TG9. Southern analysis of BAC clones Blb22, Blb25, TG9, and TG77 using an RGHspecific PCR fragment amplified from BAC clone Blb25 as a probe identified a minimum of two RGH on BAC Blb25 and TG9 and one RGH on TG77 located on the overlapping part with TG9 (Fig. 1).

Libraries harboring random overlapping binary subclones of 8 to $10 \mathrm{~kb}$ were generated from BAC clones Blb25 and TG9. In total, 1,152 clones per library were screened for the presence of RGH using primers 4-GLO2-F and 4-GLO2-R (Table 1). Based on restriction analyses of the PCR fragments, RGH-positive subclones were divided into separate classes: $B l b 3 G H-A$ and $B l b 3 G H-B$ for Rpi-blb3 and AbptGH-A and AbptGH-B for Rpiabpt. After determining the relative positions of the RGH within the 8- to $13-\mathrm{kb}$ subclones, candidates from each class were tar- 
geted for transformation to the susceptible potato cv. Desiree. Transformation experiments carried out with subclones harboring candidates $B l b 3 G H-A, B l b 3 G H-B, A b p t G H-A$, and $A b p t G H$ $B$ resulted in numerous primary transformants. Detached leaf assays using isolates IPO-0 and 90128 revealed that all of the plants transformed with subclones harboring candidates $B l b 3 G H-A, A b p t G H-A$, and $A b p t G H-B$ were susceptible to both isolates but that the majority (seven of eight) of the tested transgenic plants harboring $B l b 3 G H-B$ reacted to both isolates with an HR (Fig. 2). In view of the differential response between the primary transformants harboring $B l b 3 G H-A$ and $B l b 3 G H-B$, we designated $B l b 3 G H-B$ as the Rpi-blb3 gene.
In order to identify additional candidate genes for Rpi-abpt, the Rpi-abpt-specific BAC library was screened with TG77-S, leading to the identification of the TG77 overlapping BAC clone TG92 (Fig. 1B). Screening of this BAC clone with different sets of primers designed to amplify AbptGH-A, $A b p t G H-B, B l b 3 G H-A$, or Rpi-blb3 resulted in the identification of a third Rpi-abpt candidate gene, AbptGH-C (Fig. 1B). The $A b p t G H-C$ LRR domain was amplified, cloned, and sequenced using the primers Blb3-LRR-1-8 (Table 1). Sequence comparison of the three abpt-GHs enabled us to design an Abpt $\mathrm{GH}$-C-specific marker (Fig. 1B) which cosegregated with resistance. Southern blot analysis using the AbptGH-C ampli-
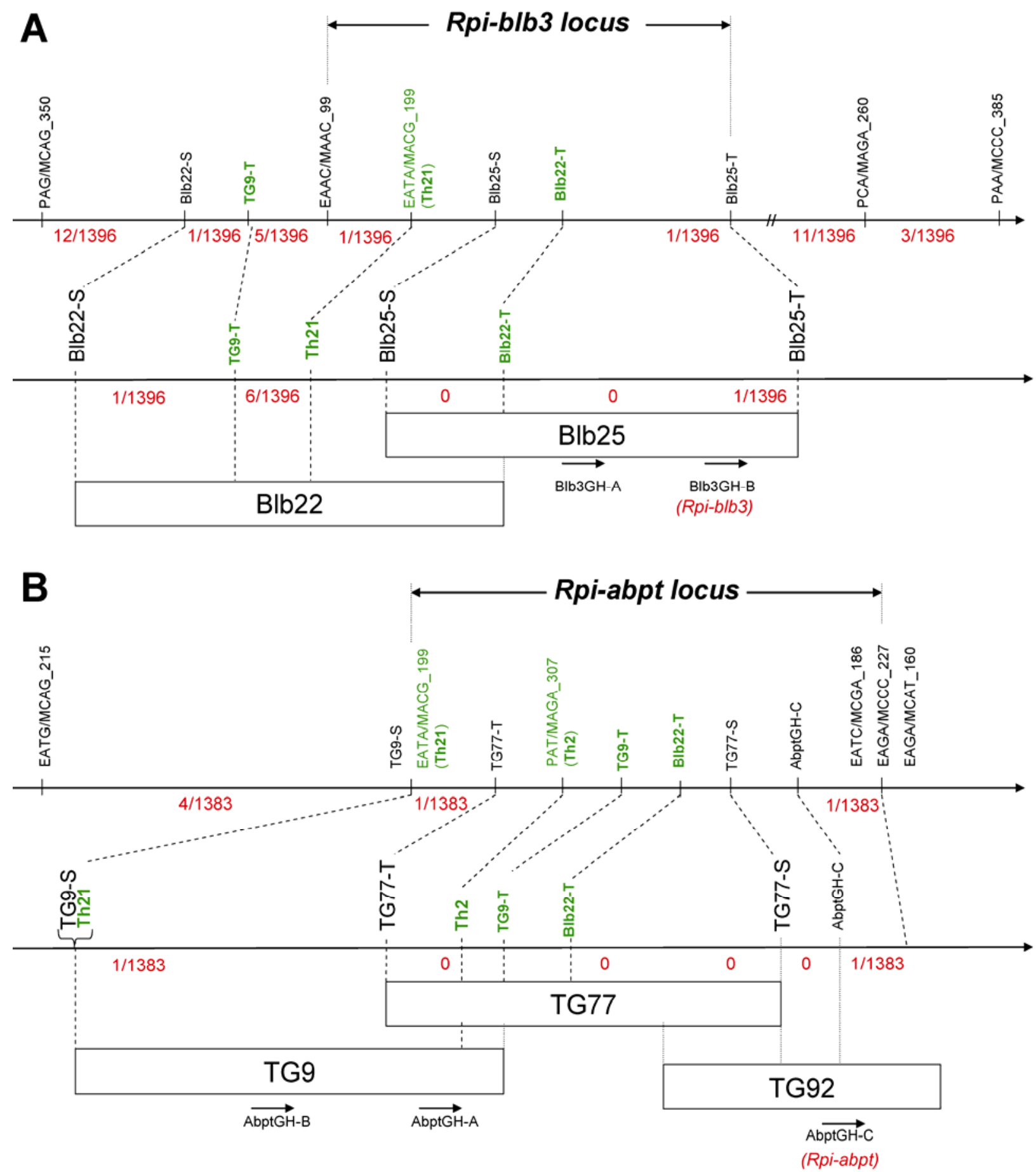

Fig. 1. Genetic and physical map of the A, Rpi-blb3 and B, Rpi-abpt loci. Indicated are the relative positions of markers (in green are the one used in the mapping of both genes), the number of recombinants identified between markers, the overlapping BAC clones defining the two loci, and the relative positions of the resistance $(R)$ gene candidates that have been targeted for complementation analysis. 
con as a probe revealed that clone TG92 contained one resistance gene encompassing an LRR domain highly similar to the one of AbptGH-C. Primers designed on the start and stop codon of Rpi-blb3 were subsequently used to amplify a fulllength AbptGH-C amplicon from clone TG92, which was cloned into the Gateway entry vector pDONR221. Using Multisite Gateway technology, the $A b p t G H-C$ amplicon was subsequently cloned into the binary $\mathrm{pKGW}-\mathrm{MG}$ destination vector between Rpi-blb3-derived promoter and terminator sequences of 2,723 and 883 nucleotides, which were cloned into pDONR P4-P1R and pDONR P2R-P3 (Supplementary Fig. S1).

Complementation analysis was carried out in N. benthamiana using the Agrobacterium tumefaciens transient assay, whereby leaves from 4-week-old wild-type $N$. benthamiana plants were infiltrated with the Agrobacterium COR308 containing pKGW-AbptGH-C. The binary clones pBP-Rpi-blb3 and pKGW-Rpi-blb3, comprising the genomic Rpi-blb3 gene and a Multisite Gateway reconstituted Rpi-blb3 gene construct, respectively, were used as positive controls and pBP-AbptGH-A as a negative control. After 2 days, infiltrated leaves were inoculated with $P$. infestans strains PY23, IPO-0, and IPO-C in detached-leaf assays. Leaves infiltrated with pKGW-AbptGHC, pBP-Rpi-blb3, and pKGW-Rpi-blb3 developed HR at the inoculation sites whereas noninfiltrated leaves and those infiltrated with pBP-AbptGH-A were susceptible to isolate PY23 and IPO-0. As expected, all leaves inoculated with IPO-C were susceptible (Fig. 3; Table 2). In view of these results, AbptGH$C$ was designated Rpi-abpt.

\section{Allele mining for $\boldsymbol{R} 2$ and $\boldsymbol{R} 2$-like.}

Rpi-blb3 and Rpi-abpt belong to the major late blight resistance locus on LG IV that also harbors $R 2$ and $R 2$-like (Li et al. 1998; Park et al. 2005c). In view of the conserved marker order and observed allelic conservation between the genetic maps of Rpi-blb3, Rpi-abpt, R2, and R2-like (Park et al. 2005c) and the high sequence conservation between Rpi-blb3 and Rpi$a b p t$, we hypothesized that $R 2$ and $R 2$-like were orthologues of Rpi-blb3 and, thus, attempted to clone them through an allelemining strategy. The same primers used to amplify the Rpiabpt candidate gene from BAC clone TG92 were used to amplify full-length Blb3GH from the resistant parental genotypes Cebeco44158-4 (MaR2) and AM3778-16 harboring R2 and R2like, respectively. Amplicons of the expected size were cloned into pDONR221 and fully sequenced. In total, 8 unique sequences were obtained from AM3778-16 (R2-likeGH) and 19 from Cebeco44158-4 (R2GH), with amino acid identities between Rpi-blb3 and the novel Blb3GH ranging from 86.4 to $97.3 \%$ for R2-likeGH and 83.8 to $94.2 \%$ for R2GH (Supplementary Tables S1 and S2). Phylogenetic analysis of all the available amino acid sequences clustered one R2-like-GH and five $\mathrm{R} 2 \mathrm{GH}$ in a clade together with the functional proteins Rpi-blb3 and Rpi-abpt (Fig. 4). The amino acid sequence of R2-likeGH-8 shares $97.3 \%$ amino acid identity with Rpi-blb3. R2GH-2, R2GH-8, R2GH-G3, R2GH-D3, and R2GH-65 share 94.2, 91, 92.6, 89.7, and 92.8\% amino acid identity, respectively, with Rpi-blb3. This set of candidate genes was targeted for functional analysis and, therefore, cloned into the binary vector pKGW-MG between the Rpi-blb3 promoter and terminator sequences, as described above for the Rpi-abpt gene.

Transient complementation assays in $N$. benthamiana indicated that R2GH-G3 and R2-likeGH-8 conferred resistance to $\mathrm{Pi}$ isolate IPO-0, whereas R2GH-2, R2GH-8, R2GH-D3, and R2GH-65 were nonfunctional (Fig. 3). Therefore, R2GH-G3 and R2-likeGH-8 were designated $R 2$ and $R 2$-like, respectively.

Table 1. Overview of markers and primers used for mapping and cloning of Rpi-blb3

\begin{tabular}{|c|c|c|c|c|}
\hline Name & Type & Polymerase chain reaction primer $\left(5^{\prime}\right.$ to $\left.3^{\prime}\right)$ & $\mathbf{T m}^{\mathrm{a}}$ & Enzyme $^{b}$ \\
\hline Th21 & SCAR & $\begin{array}{l}\text { F: ATTCAAAATTCTAGTTCCGCC } \\
\text { R: AACGGCAAAAAAGCACCAC }\end{array}$ & $\ldots$ & a.s. \\
\hline Blb22-T & $\begin{array}{l}\text { SCAR } \\
\quad \ldots\end{array}$ & $\begin{array}{l}\text { F: CTTTATTAGTTCCAAGAGCTAC } \\
\text { R: ACCCATCCCTTTTTCCTTATC }\end{array}$ & $\ldots 6$ & $\begin{array}{l}\cdots \\
\cdots\end{array}$ \\
\hline Blb25-S & CAPS & $\begin{array}{l}\text { F: ACAGATGCTACGTCCATCAC } \\
\text { R: CTCCACATGCGATGCAAAAAG }\end{array}$ & 56 & Alu1 \\
\hline Blb25-T & CAPS & $\begin{array}{l}\text { F: TTTCGATTATGGTGAGCCTTC } \\
\text { R: TAGAAAAAGGGTGGTTGTGAC }\end{array}$ & 56 & $\begin{array}{l}\text { Hpy } 188 \\
\ldots\end{array}$ \\
\hline RGH1 & $\begin{array}{c}\text { CAPS } \\
\ldots\end{array}$ & $\begin{array}{l}\text { F: GGSAAGACCACTCTTGCAAG } \\
\text { R: GGTTTTTAAGCTGCTAATGTTG }\end{array}$ & 50 & $\begin{array}{l}\text { HpyCH4IV } \\
\ldots\end{array}$ \\
\hline RGH2 & $\begin{array}{c}\text { SCAR } \\
\quad \ldots\end{array}$ & $\begin{array}{l}\text { F: GGSAAGACCACTCTTGCAAG } \\
\text { R: TGGTYATAATYACTCTGCTGC }\end{array}$ & $\begin{array}{l}50 \\
\ldots\end{array}$ & $\begin{array}{l}\text { a.s. } \\
\ldots\end{array}$ \\
\hline RGH3 & $\begin{array}{c}\text { CAPS } \\
\ldots\end{array}$ & $\begin{array}{l}\text { F: ATGRCTGATGCMTTTRTGTC } \\
\text { R: CCYAAGTASAGAAAACACTGC }\end{array}$ & $\begin{array}{l}50 \\
\ldots\end{array}$ & $\begin{array}{l}\text { HaeIIl } \\
\ldots\end{array}$ \\
\hline $\begin{array}{l}\text { 4-PLOOP } \\
\text { 4-GLPL }\end{array}$ & $\cdots$ & $\begin{array}{l}\text { F: GGiATGGGiGGiYTiGGiARGAC } \\
\text { R: TACiACAATiGCAAGiGGTAAMCC }\end{array}$ & 68 & $\cdots$ \\
\hline 4-GLO2 & $\cdots$ & $\begin{array}{l}\text { R: TACIACAATIGCAAGIGGTAAMCC } \\
\text { F: GTGTCTCTCAAGAGTACAACAC } \\
\text { R }\end{array}$ & $\begin{array}{ll}\ldots \\
56\end{array}$ & $\begin{array}{l}\cdots \\
\cdots\end{array}$ \\
\hline Blb3-start & $\begin{array}{l}\cdots \\
\cdots\end{array}$ & $\begin{array}{l}\text { R: GCTCGAACATCAAGTAGTTTCC } \\
\text { F: ATGGCTGATGCCTTTCTRTCATTTG }\end{array}$ & $\begin{array}{l}\ldots \\
55\end{array}$ & $\begin{array}{l}\cdots \\
\cdots\end{array}$ \\
\hline Blb3-end & $\ldots$ & R: TCAGGAATCTCCTTTAAATTTGGAC & & $\ldots$ \\
\hline Blb3-prom & $\begin{array}{l}\ldots \\
\ldots\end{array}$ & $\begin{array}{l}\text { F: TCTTCCTTAGCATTCGTAGC } \\
\text { R: CTTTAGGAATACTAGTTTTGATTG }\end{array}$ & $\begin{array}{l}55 \\
\ldots\end{array}$ & $\begin{array}{l}\ldots \\
\ldots\end{array}$ \\
\hline Blb3-ter & $\begin{array}{l}\cdots \\
\cdots \\
\ldots\end{array}$ & $\begin{array}{l}\text { F: AGCTTTTCTGCCAAGCACATTGG } \\
\text { R: GTACCCTCCGTTTGTCGTTTGATC }\end{array}$ & $\dddot{55}$ & $\begin{array}{l}\cdots \\
\cdots \\
\ldots\end{array}$ \\
\hline Blb3-LRR-1-8 & $\ldots$ & $\begin{array}{l}\text { F: CTCTTTATGTATCAGACATGGC } \\
\text { R: CAACATCTTTCCACTGATCAC }\end{array}$ & 55 & $\cdots$ \\
\hline Blb3-prom -end & $\ldots$ & F: CCCCAAGTTGTATAATGGTTG & 35 & $\cdots$ \\
\hline Blb3-orf-bg & $\ldots$ & R: TGCTTGAGTGATTGAATCTCC & $\ldots$ & $\ldots$ \\
\hline Sto-orf-bg & $\ldots$ & R: GGCCATATTCAGACTGGGAG & $\ldots$ & $\ldots$ \\
\hline Blb3-spe & $\cdots$ & F: AGCTTTTTGAGTGTGTAATTGG & 55 & $\cdots$ \\
\hline
\end{tabular}

\footnotetext{
${ }^{\text {a }}$ Annealing temperature. In AF411807R, annealing temperature was $48^{\circ} \mathrm{C}$ for the first seven cycles and $54^{\circ} \mathrm{C}$ for the last 30 cycles.

${ }^{\mathrm{b}}$ Restriction enzymes that reveal polymorphism between resistant and susceptible linked alleles of the marker; a.s.: allele-specific marker showing polymorphism without digestion.
} 


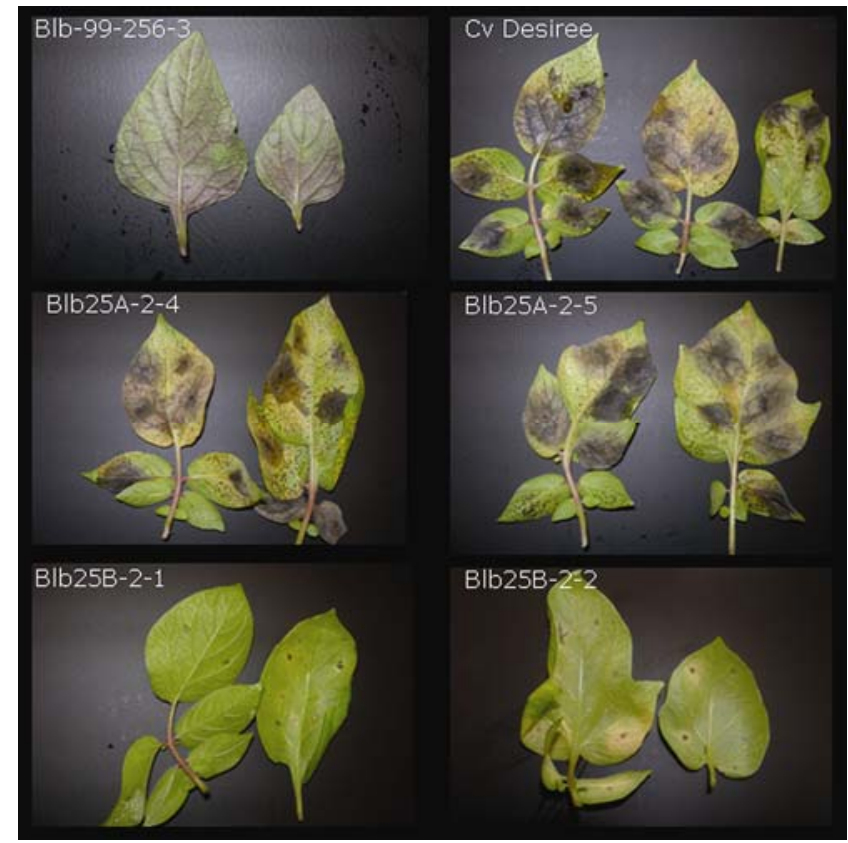

Fig. 2. Genetic complementation for late blight resistance. Eight days after inoculation with Phytophthora infestans isolate 90128, large necrotic lesions and massive sporulation were noted for potato cv. Desiree, and derived transformant Blb25A-2-4 and Blb25A-2-5, both expressing resistance gene homologue RGH-Blb25A. Typical resistance phenotype (i.e., hypersensitive response) was observed for Blb25B-2-1 and Blb25B-2-2 expressing RGH-Blb25B (Rpi-blb3).
All four $\boldsymbol{R}$ genes interact with the RXLR-EER effector PiAVR2.

Using a map-based cloning approach, markers flanking the PiAVR2 locus (van der Lee et al. 1997) were used to delimit a physical region of $742,635 \mathrm{bp}$ of the $P$. infestans genome sequence spanning the genetic interval containing PiAVR2. Within this region, two candidate $P i A V R 2$ genes on supercontig 16 of the P. infestans genome (16_7987 and 16_8044), each encoding a secreted RXLR-EER effector, were identified. The cloning and analyses of these gene candidates will be reported in detail in a separate publication (E. Gilroy, personal communication).

To functionally analyze the two RxLR-EER candidate genes identified at the PiAVR2 locus in this study, N. benthamiana leaves were co-infiltrated with A. tumefaciens strains carrying a binary construct expressing one of the four Rpi genes under study together with strains carrying a binary construct expressing each of the two candidate RxLR-EER genes. Co-infiltration of Rpi-blb3, Rpi-abpt, R2, and R2-like with 16_7987 resulted in a hypersensitive cell death response (Fig. 5), whereas co-expression of these Rpi genes with the 16_8044 candidate or PiAVR3a failed to elicit visible cell death (Fig. 5) (E. Gilroy, personal communication). Based on these results, 16_7987 was designated PiAVR2 and, clearly, all four Rpi genes under study interact with PiAVR2.

\section{Gene structure and functionality.}

Rpi-blb3, Rpi-abpt, R2, and R2-like are intronless genes which encode open reading frames (ORF) of 2,538 to 2,544 nucleotides that code for proteins of 845 to 847 amino acids harboring all the signature sequences characteristic of leucine

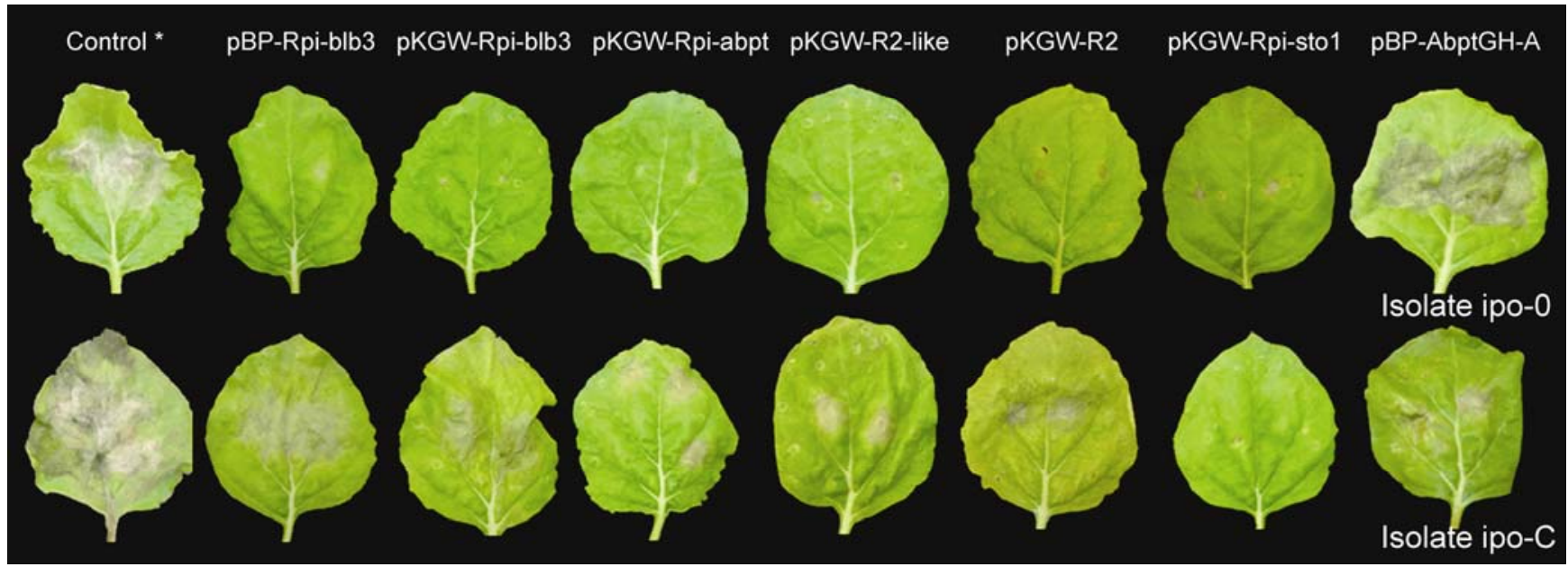

Fig. 3. Complementation of Rpi-blb3, Rpi-abpt , R2, R2-like, and Rpi-stol by transient expression in Nicotiana benthamiana, followed by inoculation by Phytophthora infestans isolate Ipo0 (avirulent) and Ipo-C (virulent on all except Rpi-stol). The prefix pBP stand for pBINplus, and pKGW stand for the gateway destination vector containing Rpi-blb3 regulatory elements. In leaves expressing pB-Rpi-blb3, pKGW-Rpi-blb3, pKGW-Rpi-abpt, pKGW-R2-like, and pKGW-R2, a hypersensitive response was observed at 7 days postinoculation with $P$. infestans isolate Ipo-0, whereas large necrotic lesions and massive sporulation were evident for $P$. infestans isolate Ipo-C. Wild-type $N$. benthamiana (Control*) and the nonfunctional AbptGH-A (pBP-AbptGH-A) were included as susceptible controls, and Rpi-sto1 (pKGW-Rpi-sto1) was included as a resistant control.

Table 2. Overview of resistance screening with a set of 16 Phytophthora infestans isolates ${ }^{\mathrm{a}}$

\begin{tabular}{|c|c|c|c|c|c|c|c|c|c|c|c|c|c|c|c|c|c|c|c|}
\hline Species & Genotype & Gene & Chr. & py 23 & IPO-0 & 90128 & H30P04 & VK98014 & IPO428-2 & Dintel & Katshaar & F95573 & EC1 & 89148-09 & 99183 & $99189^{b}$ & IPO-C & USA618 & 99177 \\
\hline BLB & Blb99-256-3 & Rpi-blb3 & 4 & $\mathrm{R}$ & $\mathrm{R}$ & $\mathrm{R}$ & $\mathrm{R}$ & $\mathrm{R}$ & $\mathrm{R}$ & $\mathrm{R}$ & $\mathrm{R}$ & $\mathrm{R}$ & $\mathrm{R}$ & $\mathrm{R}$ & $\mathrm{R}$ & $\mathrm{S}$ & S & S & S \\
\hline BLB & 707TG11-1 & Rpi-abpt & 4 & $\mathrm{R}$ & $\mathrm{R}$ & $\mathrm{R}$ & $\mathrm{R}$ & $\mathrm{R}$ & $\mathrm{R}$ & $\mathrm{R}$ & $\mathrm{R}$ & $\mathrm{R}$ & $\mathrm{R}$ & $\mathrm{R}$ & $\mathrm{R}$ & $\mathbf{R}$ & S & S & S \\
\hline BLB & AM3778-16 & R2-like & 4 & $\mathrm{R}$ & $\mathrm{R}$ & $\mathrm{R}$ & $\mathrm{R}$ & $\mathrm{R}$ & $\mathrm{R}$ & $\mathrm{R}$ & $\mathrm{R}$ & $\mathrm{R}$ & $\mathrm{R}$ & $\mathrm{R}$ & $\mathrm{R}$ & $\mathrm{S}$ & S & S & S \\
\hline \multirow[t]{3}{*}{ DMS } & Cebeco44158-4 & $R 2$ & 4 & $\mathrm{R}$ & $\mathrm{R}$ & $\mathrm{R}$ & $\mathrm{R}$ & $\mathrm{Rq}$ & $\mathrm{R}$ & $\mathrm{Rq}$ & $\mathrm{R}$ & $\mathrm{R}$ & $\mathrm{R}$ & $\mathrm{R}$ & $\mathrm{R}$ & $\mathrm{S}$ & S & S & S \\
\hline & cv. Desiree & $\ldots$ & $\ldots$ & $\mathrm{S}$ & $S$ & $\mathrm{~S}$ & $\mathrm{~S}$ & $\mathrm{~S}$ & S & $\mathrm{S}$ & S & S & S & $\mathrm{S}$ & S & $\mathrm{S}$ & S & S & S \\
\hline & cv. Bintje & $\ldots$ & $\ldots$ & $\mathrm{S}$ & $S$ & $S$ & $S$ & $S$ & $S$ & $S$ & $S$ & $S$ & $S$ & $\mathrm{~S}$ & $S$ & $S$ & $S$ & $S$ & $S$ \\
\hline
\end{tabular}

a Differential specificity is in bold. Chr. = chromosome, $\mathrm{S}=$ susceptible, $\mathrm{R}=$ resistant, and $\mathrm{Rq}=$ quantitatively resistant.

b Isolate differentially recognized. 


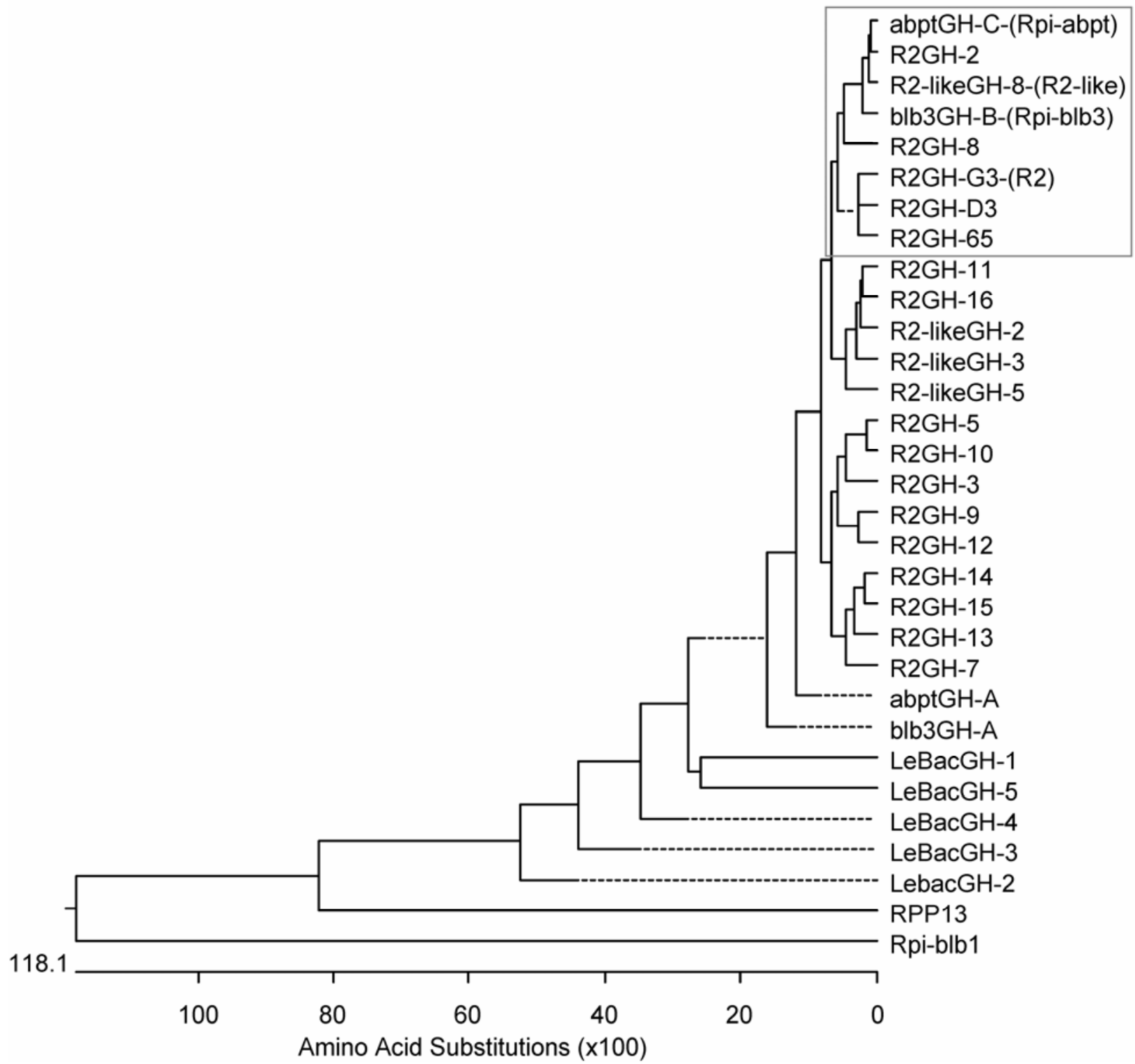

Fig. 4. Phylogenetic tree at the amino acid level of Rpi-blb3; resistance $(R)$ gene homologues (RGH) amplified from late-blight-resistant potato clones harboring Rpi-abpt, R2-like, or R2; RGH present on the tomato Bac clone AF411807, RPP13-Nd, and Rpi-blb1. The group containing Rpi-blb3, Rpi-abpt, R2, and R2-like is boxed.

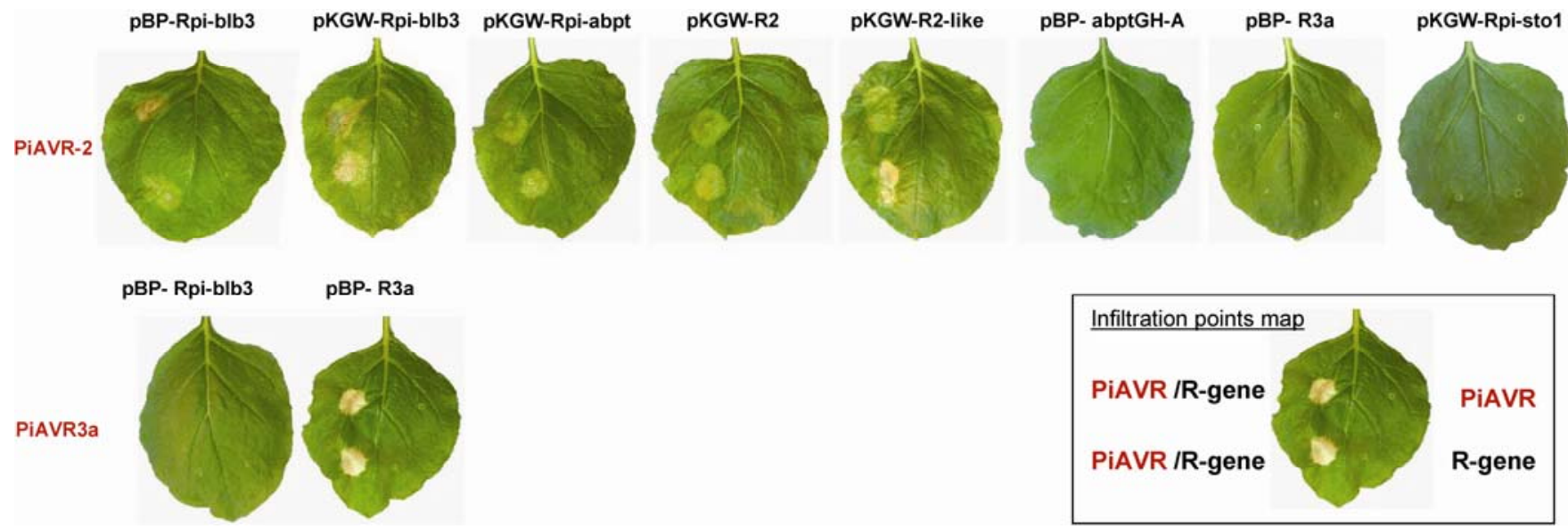

Fig. 5. Agrobacterium-mediated coexpression of PiAvr2 or PiAvr3a together with Rpi-blb3, Rpi-abpt, R2, R2-like, Rpi-sto1, the nonfunctional abptGH-A, or $R 3 a$. Different infiltration points are indicated on the map. On each leaf, four infiltration spots were performed, duplicated co-infiltration of the avirulence $(A v r)$ and resistance $(R)$ gene on the left, Avr on the top right and $R$ gene on the bottom right. Rpi-blb3, Rpi-abpt, R2, and R2-like in combination with PiAvr2 as well as $R 3 a$ and PiAvr $3 a$ induced the hypersensitive response. Pictures were taken 6 days postinfiltration. 
zipper (LZ)-NBS-LRR R proteins (Fig. 6). Interestingly, with respect to known functional $\mathrm{R}$ proteins, Rpi-blb3, Rpi-abpt, $\mathrm{R} 2$, and R2-like share the highest similarity (34.9\% amino acids) with RPP13 from Arabidopsis thaliana (Bittner-Eddy et al. 2000), which confers resistance to $H$. arabidopsidis isolates containing ATR13. The highest similarity with RPP13 resides in the NBS domain, with $49.3 \%$ sequence identity, and the lowest within the LRR domain (34.3\%). The LRR domains of Rpi-blb3, Rpi-abpt, R2, and R2-like are highly homologous and comprise 14 imperfect repeats (Fig. 6). The LZ and NBS domains are more polymorphic, those of $\mathrm{R} 2$ being the most divergent. Rpi-abpt and R2-like are identical except for the sequence between LRR2 and LRR3, where Rpi-abpt contains a stretch of amino acids that is identical to that of R2. The LRR domain of R2 is identical to that of Rpi-abpt (Fig. 6).

Alignment of the nucleotide sequences of the four functional genes and those of four additional Blb3GHs and subsequent analysis of informative polymorphic sites (IPS), (i.e., sites where two or more genes carry the same nucleotide) (Parniske et al. 1997) reveals clear blocks of sequence affiliation between different members of the gene family (Supplementary Fig. S2), indicating that sequence exchange events between $\mathrm{Blb} 3 \mathrm{GH}$ have been involved in the evolution of the gene family. Interestingly, the observed sequence affiliations in the $5^{\prime}$ terminal half of the genes extend throughout the LZ and NBS domains whereas sequence affiliations in the LRR domain suggest exchange of specific combinations of LRR, underlining the modular nature of $\mathrm{R}$ proteins.

In an attempt to assess the biological relevance of the observed sequence exchange events in relation to resistance spectrum, detached leaves of the parental clones harboring Rpiblb3 (Blb99-256-3), Rpi-abpt (707TG11), R2 (Cebeco441584(MaR2)), and R2-like (AM3778-16) were inoculated with 16 different $P$. infestans isolates (Table 2). For 15 isolates, all four clones displayed the same specificity. However, one isolate, PIC99189, displayed a differential interaction; Blb99-256-3, AM3778-16, and Cebeco44158-4 (MaR2) were susceptible to this isolate whereas 707TG11-1 was resistant (Table 2). Previously, it was reported that 707TG11-1 contained tuber-specific R1-like (Park et al. 2005d) and foliage-specific R3-haplotype (Huang 2005). To dissect the resistance specificity of 707TG11-1, we inoculated 48 F1 progeny plants of the Rpiabpt mapping population RH4x103 with isolates 90128 and PIC99189. For both isolates, a clear 1:1 segregation of resistance was observed but there was no correlation between resistance to both isolates, confirming that the resistance to isolate PIC99189 is, indeed, the result of a second gene other than Rpi-abpt, and not located on LG IV.

In order to confirm the functionality of Rpi-abpt, R2-like, and $R 2$, transgenic Desiree were generated. Detached leaves of six, five, and two independent transgenic lines expressing $R 2$ like, Rpi-abpt, and $R 2$, respectively, were inoculated with $P$. infestans isolates IPO-0 and IPO-C. All transformants reacted with an HR to isolate IPO-0 and were susceptible to isolate IPO-C (Supplementary Fig. S3). This result confirms that Rpiabpt, $R 2$-like, and $R 2$ are functional $R$ genes with expected specificity to $P$. infestans isolates. Moreover, the use of the $N$. benthamiana transient complementation assay as an efficient tool for rapid functional screen of putative $R$ genes is verified.

\section{DISCUSSION}

In this study, we describe the cloning and functional characterization of four homologous $R$ genes from the major late blight resistance locus on LG IV of potato. Previously, marker order and allelic conservation suggested that Rpi-blb3, Rpiabpt, $R 2$, and $R 2$-like reside at the same locus on LG IV (Park et al. 2005a, b, and c). Rpi-blb3 and Rpi-abpt were cloned using a map-based cloning approach whereby physical maps of both loci were generated by screening appropriate BAC libraries with a highly linked molecular marker, followed by subsequent rescreening of the libraries with novel BAC end markers until the outer ends of the BAC contigs exceeded the genetic boundaries of the $R$ loci. In the case of Rpi-blb3, two candidate NBS-LRR genes were identified and subcloned into a binary vector and targeted for complementation analysis through stable transformation of a susceptible potato cultivar.

For Rpi-abpt, an NBS-LRR candidate was cloned from the BAC using a homology-based PCR cloning strategy using primers designed on the functional Rpi-blb3 gene. In addition, complementation was carried out using an Agrobacterium-mediated transient expression assay in $N$. benthamiana followed by detached leaf assays with appropriate $P$. infestans isolates (H. Rietman, unpublished data).

Development of the transient complementation assay together with the successful in planta expression of Rpi-abpt and other $R$ genes (H. Rietman, unpublished data) using the DNA regulatory elements of $R p i-b l b 3$ facilitated the rapid cloning of $R 2$ and $R 2$-like through an efficient functional allele-mining strategy. A prerequisite for such an allele-mining strategy is prior knowledge of candidate gene sequences at the locus of interest. Observations within the family Solanaceae indicate that $R$ gene clusters are conserved across species, thus enabling comparative genomics (Grube et al. 2000; Huang. 2005; van der Vossen et al. 2005). As more and more $R$ genes are mapped and cloned, the greater is the chance that novel $R$ genes reside at known and well-characterized loci. Moreover, ongoing potato and tomato genome-sequencing projects by international consortia promise to provide a complete survey of the distribution of $R$ gene clusters in the family Solanaceae, enabling even faster cloning of $R$ genes through allele-mining strategies.

Interestingly, with respect to known functional $\mathrm{R}$ proteins, Rpi-blb3, Rpi-abpt, R2, and R2-like share the highest similarity $(34.9 \%$ amino acids) with RPP13 from A. thaliana (BittnerEddy et al. 2000), which confers resistance to $H$. arabidopsidis. Mining of RPP13 alleles in a diverse set of A. thaliana accessions revealed both extreme sequence diversity and functional diversity in pathogen recognition (Rose et al. 2004). In line with this observation, a significant excess of amino acid polymorphism was localized within the LRR domain of RPP13. In the case of Rpi-blb3, Rpi-abpt, R2, and R2-like, the LRR domains are nearly identical despite significant polymorphism at the coiled-coil and NBS domains, suggesting conservation of function; and, indeed, we have shown that all four proteins interact with the same effector protein, PiAVR2, which was recently cloned through a map-based cloning approach (E. Gilroy, personal communication). Although the origin of Rpi-abpt and R2-like remain unclear, this finding is a second example of how $R$ gene recognition specificities can be conserved across Solanum spp. originated from different potato superseries; in this case, S. bulbocastanum (Rpi-blb3) belongs to the Potato Stellata Bulbocastana and S. demissium (R2) to the Potato Rotata demissa. Recently, we demonstrated both gene conservation and specificity conservation between the $S$. bulbocastanum-derived gene Rpi-blb1 and the $S$. stoloniferum- and S. papita-derived orthologues Rpi-stol and Rpiptal, respectively (Vleeshouwers et al. 2008). Despite apparent positive selection in the LRR domain, the LZ and NBS domains are more polymorphic, those of $\mathrm{R} 2$ being the most divergent. Clear blocks of sequence affiliation between the four functional $\mathrm{R}$ proteins and additional Rpi-blb3 gene homologs suggest exchange of LZ, NBS, and LRR domains and also of specific LRR, underlining the modular nature of these proteins. $R 2$ has a particular gene structure likely to be the 


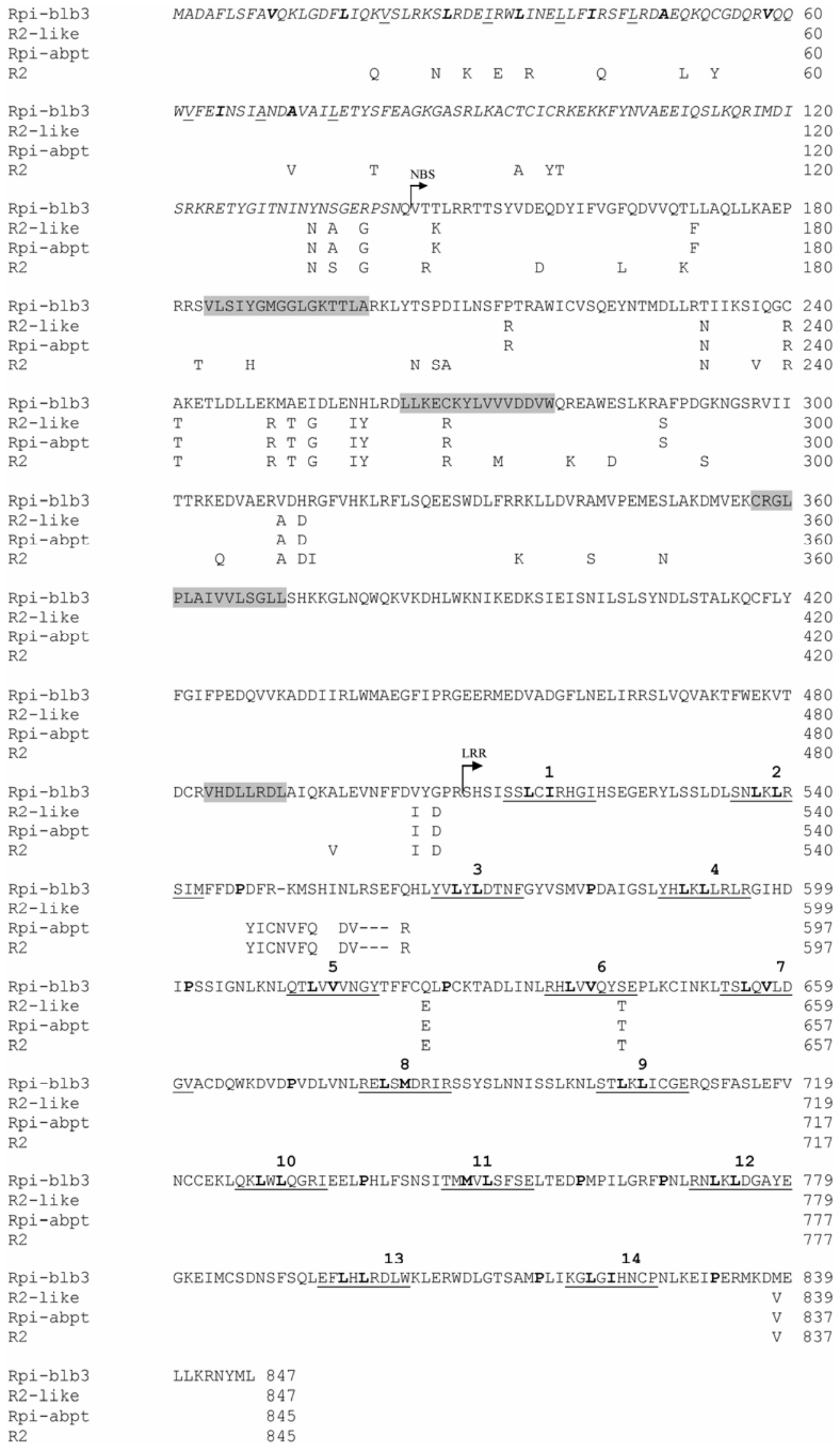

Fig. 6. Alignment of the deduced protein product encoded by the functional genes Rpi-blb3, Rpi-abpt, R2-like, and R2. The full amino acid sequence of Rpi$b l b 3$ and in comparison, differing amino acids of Rpi-abpt, R2-like, and $R 2$ are shown. In italics is the leucine zipper domain with the first and the fifth hydrophobic residues from the heptads in bold and underlined, respectively. Positions of the nucleotide binding (NB)-ARC and leucine-rich repeat are indicated by arrows. The NB-ARC domain has its characteristic conserved domains highlighted in gray (kinase 1a, kinase 2, and kinase 3). The leucine-rich repeat domain is composed of 14 repeats with the motif xxLxLxxx. 
product of a relatively recent recombination event. The LZNBS domain (nucleotides 1 to 1,149 ) is highly affiliated to that of the nonfunctional $R 2-G H-D 3$, whereas the LRR domain (nucleotides 1,059 to 2,544) is highly affiliated to that of Rpiabpt and the nonfunctional $R 2-G H-65$, revealing a sequence exchange track between nucleotides 1,059 and 1,149. Sequence exchange between RGH has been proposed as a major mechanism shaping $R$ gene diversity in plants (Kuang et al. 2004; Meyers et al. 1999; Michelmore and Meyers 1998). Interestingly, the approximate position of this recombination site corresponds to the one described by Rose and associates (2004) for the $R P P 13$ allele $k s k-2$, a region between the conserved GLPL and VHD motifs of the NB-ARC domain. This is in line with the expectation that, in multidomain proteins, sequence exchange tracks will be concentrated at specific sites that separate domains with independent functions.

Preliminary results from ongoing Rpi-blb3 allele-mining studies in Solanum germplasm indicate that Rpi-blb3 is present in several other species (e.g., S. brachistotrichum and $S$. pinnatisectum). In addition several Rpi genes recently identified in our laboratory (data not shown) also map to the Rpiblb3 interval. The quantitative trait locus (QTL) for late blight resistance (Pi-QTL) (Sandbrink et al 2000), explaining $40 \%$ of the phenotypic variation, was mapped to the Rpi-blb3 locus and renamed Rpi-mcdl (Tan et al. 2008). Similarly, high-resolution mapping data of the major Pi-QTL identified in cv. Stirling strongly suggest that this Pi-QTL is also an Rpi-blb3 homologue (Hein et al. 2007) (I. Hein, personal communication). In addition, various other examples of Pi-QTL on the short arm of LG IV have been described (Bradshaw et al. 2004, 2006; Leonards-Schippers et al. 1994; Sandbrink et al. 2000).

Rpi-blb3, Rpi-abpt, R2, and R2-like specifically detect PiAVR2. Do the Rpi-blb3 homologues putatively underlying the Pi-QTL described above also recognize PiAVR2 homologues? If so, do they weakly recognize an allele that is conserved throughout $P$. infestans or do they recognize multiple alleles, thus resulting in nonrace-specific resistance?

Current models for NB-LRR R proteins suggest a dual role for the LRR domain, not only as recognition specificity determinant but also as a repressor of inappropriate NB activation (Belkhadir et al. 2004). Furthermore, evolutionary analyses of $\mathrm{R}$ proteins and their structure has shown selection pressure on the LRR region but also on other domains within $\mathrm{R}$ proteins which, in light of the dual function, may point toward coevolution in $\mathrm{R}$ proteins to establish and maintain recognition of effectors while maintaining the inhibitory function (McDowell and Simon 2006). Our findings are slightly different, contradictory, indicating conservation in the LRR domain but more variation in the NBS domain, that may point toward different signaling pathways or additional effectors being recognized by these $\mathrm{R}$ proteins.

\section{MATERIALS AND METHODS}

\section{Plant material and $P$. infestans isolates.}

In this study, we used the four resistant parental clones Blb99-256-3 harboring Rpi-blb3 (Park et al. 2005a), 707TG11-1 Rpi-abpt (Park et al. 2005c), Cebeco44158-4 (MaR2), R2, and AM3778-16 R2-like (Park et al. 2005b). F1 progeny plants of population RH4x103 were derived from a cross between the late-blight-resistant clone 707TG11-1 and the diploid potato clone RH89-039-16 (Park et al. 2005c). The susceptible potato cv. Desiree was used for Agrobacterium-mediated transformation. The characteristics and origin of $P$. infestans isolates used in this study are indicated in Supplementary Table S3.

\section{BAC library construction.}

Clones Blb99-256-3 and 707TG11-1 were used as DNA sources for the construction of BAC libraries. High molecular weight DNA preparation and BAC library construction were carried out as described previously (Rouppe van der Voort et al. 1999). Approximately 74,000 clones with an average insert size of $85 \mathrm{~kb}$, corresponding to eight genome equivalents, were obtained per library. The BAC clones were stored as bacterial pools containing approximately 700 to 1,000 white colonies. These were generated by scraping the colonies from the agar plates into Luria-Bertani (LB) medium containing $18 \%$ glycerol and chloramphenicol at $12.5 \mu \mathrm{g} \mathrm{ml}^{-1}$ using a sterile glass spreader. These so-called super pools were stored at $-80^{\circ} \mathrm{C}$. Marker screening of the BAC libraries was done, first by isolating plasmid DNA from each pool using the standard alkaline lysis protocol, and PCR was carried out to identify positive pools. Bacteria corresponding to positive pools were diluted and plated on LB agar plate containing chloramphenicol $(12.5$ $\mu \mathrm{g} \mathrm{ml}^{-1}$ ). Individual white colonies were picked into 384-well microtiter plates and single positive BAC clones were subsequently identified by marker screening as described by Rouppe van der Voort and associates (1999). Names of BAC clones isolated from the super pools carry the prefix Blb (e.g., Blb25) or TG (e.g., TG9).

\section{Subcloning of candidate genes.}

Candidate RGH were subcloned from BAC clone BLB25 and TG9 as follows. Aliquots of approximately $1 \mu \mathrm{g}$ of BAC DNA were digested with $0.03 \mathrm{U}$ of Sau3Al restriction enzyme for $10 \mathrm{~min}$. The partially digested BAC DNA was subjected to electrophoresis at room temperature in $0.5 \times$ Trisacetate EDTA using a linear increasing pulse time of 1 to 10 $\mathrm{s}$ and a field strength of $90 \mathrm{~V} \mathrm{~cm}^{-1}$ for $6 \mathrm{~h}$. After electrophoresis, the agarose gel was stained with ethidium bromide to locate the region of the gel containing DNA fragments of approximately $10 \mathrm{kbp}$ in size. This region was excised from the gel and treated with GELASE (Epicentre Technologies, Madison, WI, U.S.A.) according to the manufacturer's instructions. The size-selected DNA was ligated to the BamHIdigested and dephosphorylated binary vector pBINPLUS (van Engelen et al. 1995) followed by transformation to ElectroMAX Escherichia coli DH10B competent cells (Life Technologies, Paisley, U.K.).

\section{DNA sequencing and computer analysis.}

BAC clone sequencing was carried out using a shotgun cloning strategy. Sequencing reactions were performed using a dye terminator cycle sequencing reaction kit (Perkin-Elmer, $\mathrm{Pt}$ Biosystem, Warrington, U.K.), M13 universal forward and reverse primers, and an ABI377 automated sequencer (Applied Biosystem, La Jolla, CA, U.S.A.). Sequence contigs were assembled using the STADEN sequence and analysis program (Dear and Staden 1991).

The binary constructs were sequenced using a primer walking strategy ( 700 by $700 \mathrm{bp}$ ). Gene structures were predicted using FGENESH++ (Softberry) and protein sequences were deduced by translation of the ORF using the standard genetic code. Multiple sequence alignments were conducted using CLUSTALX 1.81 (Thompson et al. 1997). The search for genes homologous to Rpi-blb3 was carried out using the Basic Local Alignment Search Tool (BLAST). Conserved domains were identified using Swiss-Prot (InterProScan, EMBL-EBI, ExPASy, SAPS).

\section{Resistance assay.}

Detached leaf assays were used to determine the resistance phenotypes of primary transformants of potato and transiently 
transformed $N$. benthamiana leaves. For complementation analyses, primary transformants were tested with isolates IPO0 and 90128 (Fig. 2). Inoculum preparations and inoculations were performed as described by Vleeshouwers and associates (1999). Six days after inoculation, plant phenotypes were determined. Leaves showing no symptoms or a localized necrosis at the point of inoculation were scored as resistant and those with clear sporulating lesions (visible by naked eye) as susceptible.

\section{Transient complementation in $N$. benthamiana.}

Infiltrations of Agrobacterium strains carrying the candidate RGH were performed in $N$. benthamiana. Recombinant COR308 Agrobacterium tumefaciens cultures were grown in LB medium (10 $\mathrm{g}$ of bacteriological peptone, $10 \mathrm{~g}$ of $\mathrm{NaCl}$, and $5 \mathrm{~g}$ of yeast extract in 1 liter of milli-Q water) supplemented with tetracycline at $5 \mathrm{mg} / \mathrm{liter}$ and kanamycin at 50 $\mathrm{mg} / \mathrm{liter}$. After 1 or 2 days, a calculated amount of culture (according to an optical density at $600 \mathrm{~nm}\left[\mathrm{OD}_{600}\right]$ of 0.5 ) was transferred to YEB medium (5 $\mathrm{g}$ of beef extract, $5 \mathrm{~g}$ of bacteriological peptone, $5 \mathrm{~g}$ of sucrose, $1 \mathrm{~g}$ of yeast extract, and 2 $\mathrm{ml}$ of $1 \mathrm{M} \mathrm{MgSO}_{4}$ in 1 liter of milli-Q water) supplemented with kanamycin for all strains. After 1 day, overnight cells were centrifuged at 3,500 rpm and resuspended in MMA medium (20 g of sucrose, $5 \mathrm{~g}$ of MS salts, and $1.95 \mathrm{~g}$ of morpholineethanesulfonic acid) supplemented with $1 \mathrm{ml}$ of 200 $\mathrm{mM}$ acetosyringone to a final $\mathrm{OD}_{600}$ of 0.2 and infiltrated into leaves of 4-week-old plants with a 3-ml syringe. After 2 days, infiltrated leaves were detached and inoculated with $P$. infestans strains IPO-C and PY23 in detached-leaf assays. HR or P. infestans sporulation was observed between 4 and 8 days postinoculation.

\section{Agrobacterium-mediated coexpression in $N$. benthamiana.}

pBP-Rpiblb3, pKGW-Rpi-blb3, pKGW-Rpi-abpt, $p K G W-R 2$, $p K G W$-R2-like, $p K G W$-Rpi-sto1, $p B P$-abptGH-A, and $p B P$ $R 3 a$ were transferred to $A$. tumefaciens AGL1 (Lazo et al. 1991) containing the helper plasmid pVirG and pSoup (van der Fits et al. 2000). Recombinant A. tumefaciens cultures were grown in LB medium supplemented with tetracycline at 5 $\mathrm{mg} / \mathrm{liter}$, carbenicillin at $100 \mathrm{mg} / \mathrm{liter}$, chloramphenicol at 75 $\mathrm{mg} / \mathrm{liter}$, and kanamycin at $50 \mathrm{mg} / \mathrm{liter}$. The avirulence effectors were cloned into the pGRAB vector (kindly supplied by Sean Chapman, SCRI, Scotland, U.K.) and transferred to the same A. tumefaciens AGL1. Recombinant A. tumefaciens cultures were grown in LB medium supplemented with chloramphenicol at $30 \mathrm{mg} / \mathrm{liter}$ and kanamycin at $50 \mathrm{mg} / \mathrm{liter}$. The same protocol as for the transient complementation was used for the subcultures. PiAVR Agrobacterium culture and Rpigene Agrobacterium culture were mixed at a final $\mathrm{OD}_{600}$ of 0.1 for each and infiltrated into leaves from 5- to 7-week-old plants. Specific recognition of the $A V R$ gene by the $R$ gene induces HR from 5 days postinfiltration.

\section{Transformation of susceptible potato cultivar.}

Binary plasmids harboring the candidate genes $B l b 3 G H-A$, $B l b 3 G H-B, A b p t G H-A$, and $A b p t G H-B$ were transferred to $A$. tumefaciens COR308 (Hamilton et al. 1996) and the constructs pKGW-Rpi-abpt, pKGW-R2-like, and pKGW-R2 in AGL1 (Lazo et al. 1991). After verifying their stability in Agrobacterium spp., these clones were transformed to the susceptible potato cv. Desiree. Overnight cultures of the transformed A.tumefaciens strain were used to transform internodal cuttings from in vitro grown plants (Heilersig et al. 2006). A total of 100 to 200 explants were used for each transformation. Three to eight plants per transformant were transferred to the greenhouse.

\section{Allele mining.}

Primers of 32 nucleotides were designed on the Rpi-blb3 sequence, with the forward primer beginning at the start codon (Blb3-start) and the reverse primer beginning at the stop codon (Blb3-end) (Table 1). The BAC clone TG92 containing Rpiabpt and the genomic DNA of the parental resistant genotype AM-(3778-16) containing R2-like were used as template in a long-range PCR reaction $\left(95^{\circ} \mathrm{C}\right.$ for $2 \min 40 \mathrm{~s} ; 30 \times\left[94^{\circ} \mathrm{C}\right.$ for $20 \mathrm{~min}, 56.8^{\circ} \mathrm{C}$ for $25 \mathrm{~min}$, and $64.3^{\circ} \mathrm{C}$ for $7 \mathrm{~min}$ ], and $64.3^{\circ} \mathrm{C}$ for $25 \mathrm{~min}$ ) using the high-fidelity DNA polymerase PfuTurbo (Stratagene, La Jolla, CA, U.S.A.). PCR products were separated on agarose gel and purified using the QIAquick gel extraction kit from Qiagen (Hilden, Germany). The purified pool of R2-likeGH ORF and the purified Rpi-abpt ORF were used in a $\mathrm{BP}$ reaction together with the donor plasmid pDONR 221 according to the protocol described by Untergasser (2006b). Subsequently, the BP reaction products were transferred to DH10B E. coli competent cells and plated on LB agar plates containing the antibiotic kanamycin at the concentration of $100 \mu \mathrm{g} / \mathrm{ml}$. Colonies were cultured in LB liquid medium supplemented with kanamycin. Plasmid DNA was subsequently extracted by mini-prep protocol adapted from Sambrook and associates (1989) using the P1, P2, and P3 solutions from Qiagen. The first and last 700 bp of plasmids containing R2likeGH ORF were sequenced and classified. Then, one clone of each group was entirely sequenced and compared with the Rpi-blb3 sequence. The clones sharing high similarity with Rpi-blb3 were cloned into the destination vector pKGW-MG (kindly provided by Andreas Untergasser) in between Rpi-blb3 regulatory elements via a multiple LR reaction with the $R p i$ blb3 promotor in pDONR-P4P1R, the Rpi-blb3 terminator in pDONR-P2RP3, the ORF of interest in pDONR221, and the binary destination using the protocol of Untergasser (2006a). The final expression constructs were then transferred to $A$. $t u$ mefaciens COR308 after the configuration of the constructs was confirmed by PCR.

\section{ACKNOWLEDGMENTS}

A. A. Lokossou is supported by the Wageningen University Fund. P. R $\mathrm{J}$. Birch is supported by the Scottish Government Rural and Environment Research and Analysis Directorate (RERAD) and J. Morales is supported by EU Alßan. We thank V. Vleeshouwers and I. Hein for critically reading the manuscript and M. Fiers and P.-Y. Chibon for their help in bio-informatics.

\section{LITERATURE CITED}

Allen, R. L., Bittner Eddy, P. D., Grenville Briggs, L. J., Meitz, J. C., Rehmany, A. P., Rose, L. E., and Beynon, J. L. 2004. Host-parasite coevolutionary conflict between Arabidopsis and downy mildew. Science 306:1957-1960.

Allen, R. L., Meitz J. C, Baumber R. E., Hall S. A., Lee S. C., Rose L. E., and Beynon J. L. 2008. Natural variation reveals key amino acids in a downy mildew effector that alters recognition specificity by an Arabidopsis resistance gene. Mol. Plant Pathol.9:511-523.

Armstrong, M. R., Whisson, S. C., Pritchard, L., Bos, J. I. B., Venter, E., Avrova, A. O., Rehmany, A. P., Böhme, U., Brooks, K., Cherevach, I., Hamlin, N., White, B., Fraser, A., Lord, A., Quail, M. A., Churcher, C., Hall, N., Berriman, M., Huang, S., Kamoun, S., Beynon, J. L., and Birch, P. R. J. 2005. An ancestral oomycete locus contains late blight avirulence gene Avr3a, encoding a protein that is recognized in the host cytoplasm. Proc. Natl. Acad. Sci. U.S.A. 102:7766-7771.

Ballvora, A., Ercolano, M. R., Weiss, J., Meksem, K., Bormann, C. A., Oberhagemann, P., Salamini, F., and Gebhardt, C. 2002. The Rl gene for potato resistance to late blight (Phytophthora infestans) belongs to the leucine zipper/NBS/LRR class of plant resistance genes. Plant J. 30:361-71.

Belkhadir, Y., Nimchuk, Z., Hubert, D. A., Mackey, D., and Dangl, J. L. 2004. Arabidopsis RIN4 negatively regulates disease resistance mediated by RPS 2 and RPM1 downstream or independent of the NDR1 sig- 
nal modulator and is not required for the virulence functions of bacterial type III effectors AvrRpt2 or AvrRpm1. Plant Cell 16:2822-2835.

Bergelson, J., Dwyer, G., and Emerson, J. J. 2001. Models and data on plant-enemy co evolution. Annu. Rev. Genet. 35:469-499.

Birch, P. R. J., Rehmany, A. P., Pritchard, L., Kamoun, S., and Beynon, J. L. 2006. Trafficking arms: Oomycete effectors enter host plant cells. Trends Microbiol. 14:8-11.

Birch, P. R. J., Boevink, P. C., Gilroy, E. M., Hein, I., Pritchard, L., and Whisson, S. C. 2008a. Oomycete RXLR effectors: Delivery, functional redundancy and durable disease resistance. Curr. Opin. Plant Biol. 11:373-379.

Birch, P. R. J., Whisson, S., Boevink, P., Armstrong, M., Gilroy, E., Pritchard, L., Grouffaud, S., Sandanandom, A., Taylor, R., Kamoun, S. and Bos, J. 2008b. Translocated oomycete effectors that target the plant immune system. Comp. Biochem. Physiol. A 150:S176-S177.

Bittner-Eddy, P. D., Crute, I. R., Holub, E. B., and Beynon, J. L. 2000. $R P P 13$ is a simple locus in Arabidopsis thaliana for alleles that specify downy mildew resistance to different avirulence determinants in Peronospora parasitica. Plant J. 21:177-188.

Black, L. M. 1970. Potato yellow dwarf virus. No. 35. Assoc. Appl. Biol., Wellesbourne, U.K.

Bradshaw, J., Bryan, G., Hackett, C., McLean, K., Pande, B., Stewart, H., and Waugh, R. 2004. Dissection and analysis of quantitative disease resistance in tetraploid potato. Euphytica 137:13-18.

Bradshaw, J. E., Bryan, G. J., Lees, A. K., McLean, K., and Solomon Blackburn, R. M. 2006. Mapping the R10 and R11 genes for resistance to late blight (Phytophthora infestans) present in the potato (Solanum tuberosum) R-gene differentials of Black. Theor. Appl. Genet. 112:744 751

Dear, S., and Staden, R. 1991. A sequence assembly and editing program for efficient management of large projects. Nucleic Acids Res. 19:39073911 .

de Vetten, N., Wolters, A. M., Raemakers, K., van der Meer, I., ter Stege, R., Heeres, E., Heeres, P., and Visser, R. 2003. A transformation method for obtaining marker-free plants of a cross-pollinating and vegetatively propagated crop. Nat. Biotechnol. 21:439-442.

Ewing, E. E., and Simko 2000. Genetic mapping from field tests of qualitative and quantitative resistance to Phytophthora infestans in a population derived from Solanum tuberosum and Solanum berthaultii. Mol. Breed 6:25-36.

Flor, H. H. 1971. Current status of the gene-for-gene concept. Annu. Rev. Phytopathol. 78:275-298.

Gebhardt, C., and Valkonen, J. P. 2001. Organization of genes controlling disease resistance in the potato genome. Annu. Rev. Phytopathol. 39:79102

Grube, R. C., Blauth, J. R., Arnedo, M. S., Caranta, C., and Jahn, M. K. 2000. Identification and comparative mapping of a dominant Potyvirus resistance gene cluster in Capsicum. Theor. Appl. Genet. 101:852-859.

Hamilton, C. M., Frary, A., Lewis, C., and Tanksley, S. D. 1996. Stable transfer of intact high molecular weight DNA into plant chromosomes. Proc. Natl. Acad. Sci. U.S.A. 93:9975-9979.

Hanson, P., Sitathani, K., Sadashiva, A., Yang, R.-y., Graham, E., and Ledesma, D. 2007. Performance of Solanum habrochaites LA1777 introgression line hybrids for marketable tomato fruit yield in Asia. Euphytica 158:167-178.

Heilersig, H. J. B., Loonen, A., Bergervoet, M., Wolters, A. M. A., and Visser, R. G. F. 2006. Post-transcriptional gene silencing of GBSSI in potato: Effects of size and sequence of the inverted repeats. Plant Mol. Biol. 60:647-662.

Hein, I., McLean, K., Chalhoub, B., and Bryan, G. J. 2007. Generation and screening of a BAC library from a diploid potato clone to unravel durable late blight resistance on linkage group IV. Int. J. Plant Genomics: Article ID 51421

Holub, E. B. 2001. The arms race is ancient history in Arabidopsis, the wildflower. Nat. Rev. Genet. 2:516-527.

Huang, S. 2005. Discovery and characterization of the major late blight resistance complex in potato: Genomic structure, functional diversity, and implications. Ph.D. thesis, Wageningen University, The Netherlands.

Huang, S., Vleeshouwers, V. G. A. A., Werij, J. S., Hutten, R. C. B., Eck, H. J. v., Visser, R. G. F., and Jacobsen, E. 2004. The $R 3$ resistance to Phytophthora infestans in potato is conferred by two closely linked $R$ genes with distinct specificities. Mol. Plant-Microbe Interact. 17:428435

Huang, S., van der Vossen, E. A. G., Kuang, H., Vleeshouwers, V. G. A. A., Zhang, N., Borm, T. J. A., van Eck, H. J., Baker, B., Jacobsen, E., and Visser, R. G. F. 2005. Comparative genomics enabled the isolation of the $R 3 a$ late blight resistance gene in potato. Plant J. 42:251-261.

Jacobsen, E., and Schouten, H. J. 2007. Cisgenesis strongly improves introgression breeding and induced translocation breeding of plants. Trends Biotechnol. 25:219-223.
Jones, J. D. G., and Dangl, J. L. 2006. The plant immune system. Nature 444:323-329.

Kuang, H., Woo, S.-S., Meyers, B. C., Nevo, E., and Michelmore, R. W. 2004. Multiple genetic processes result in heterogeneous rates of evolution within the major cluster disease resistance genes in lettuce. Plant Cell 16:2870-2894.

Kuhl, J. C., and Hanneman 2001. Characterization and mapping of Rpil, a late-blight resistance locus from diploid (1EBN) Mexican Solanum pinnatisectum. Mol. Genet. Genomics 265:977-985.

Lazo, G. R., Stein, P. A., and Ludwig, R. A. 1991. A DNA transformationcompetent Arabidopsis genomic library in Agrobacterium. Nat. Biotechnol. 9:963-967.

Leonards-Schippers, C., Gieffers, W., Schafer Pregl, R., Ritter, E., Knapp, S. J., Salamini, F., and Gebhardt, C. 1994. Quantitative resistance to Phytophthora infestans in potato: A case study for QTL mapping in an allogamous plant species. Genetics 137:67-77.

Li, X., Eck, H. J. v., Rouppe van der Voort, J. N. A. M., Huigen, D. J., Stam, P., and Jacobsen, E. 1998. Autotetraploids and genetic mapping using common AFLP markers: The $R 2$ allele conferring resistance to Phytophthora infestans mapped on potato chromosome 4. Theor. Appl. Genet. 96:1121-1128.

Malcolmson, J. 1969. Factors involved in resistance to blight (Phytophthora infestans (Mont.) de Bary) in potatoes and assessment of resistance using detached leaves. Ann. Appl. Biol. 64:461-468.

Malcolmson, J. F., and Black, W. 1966. New $R$ genes in Solanum demissum Lindl. and their complementary races of Phytophthora infestans (Mont.) de Bary. Euphytica 15:199-203.

McDowell, J. M., and Simon, S. A. 2006. Recent insights into $R$ gene evolution. Mol. Plant Pathol. 7:437-448.

McGillivary, J. H., and Clemente, L. J. 1956. Effect of tomato size on solids content. Proc. Am. Soc. Hortic. Sci. 68:466-469.

Meyers, B. C., Dickerman, A. W., Michelmore, R. W., Sivaramakrishnan, S., Sobral, B. W., and Young, N. D. 1999. Plant disease resistance genes encode members of an ancient and diverse protein family within the nucleotide-binding superfamily. Plant J. 20:317-332.

Michelmore, R. W., and Meyers, B. C. 1998. Clusters of resistance genes in plants evolve by divergent selection and a birth-and-death process Genome Res. 8:1113-1130.

Müller, K. O., and Black, W. 1952. Potato breeding for resistance to blight and virus diseases during the last hundred years. Z. Pflanzenzücht. 31:305-318.

Oberhagemann, P., Chatot-Balandras, C., Schäfer-Pregl, R., Wegener, D., Palomino, C., Salamini, F., Bonnel, E., and Gebhardt, C. 1999. A genetic analysis of quantitative resistance to late blight in potato: Towards marker-assisted selection. Mol. Breed. 5:399-415.

Park, T., Gros, J., Sikkema, A., Vleeshouwers, V. G. A. A., Muskens, M., Allefs, S., Jacobsen, E., Visser, R. G. F., and van der Vossen, E. A. G. 2005a. The late blight resistance locus Rpi-blb3 from Solanum bulbocastanum belongs to a major late blight $\mathrm{R}$ gene cluster on chromosome 4 of potato. Mol. Plant-Microbe Interact. 18:722-729.

Park, T. H., Vleeshouwers, V. G. A. A., Huigen, D. J., van der Vossen, E. A. G., van Eck, H. J., and Visser, R. G. F. 2005b. Characterization and high-resolution mapping of a late blight resistance locus similar to $R 2$ in potato. Theor. Appl. Genet. 111:591-597.

Park, T. H., Vleeshouwers, V. G. A. A., Hutten, R. C. B., van Eck, H. J. van der Vossen, E., Jacobsen, E., and Visser, R. G. F. 2005c. High-resolution mapping and analysis of the resistance locus Rpi-abpt against Phytophthora infestans in potato. Mol. Breed. 16:33-43.

Park, T. H., Vleeshouwers, V. G. A. A., Kim, J.-B., Hutten, R. C. B., and Visser, R. C. F. 2005d. Dissection of foliage tuber late blight resistance in mapping populations of potato. Euphytica 143:75-83.

Parniske, M., Hammond-Kosack, K. E., Golstein, C., Thomas, C. M. Jones, D. A., Harrison, K., Wulff, B. B., and Jones, J. D. 1997. Novel disease resistance specificities result from sequence exchange between tandemly repeated genes at the $C f-4 / 9$ locus of tomato. Cell 91:821-32.

Rauscher, G. M., Smart, C. D., Simko, I., Bonierbale, M., Mayton, H., Greenland, A., and Fry, W. E. 2006. Characterization and mapping of $R P i$-ber, a novel potato late blight resistance gene from Solanum berthaultii. Theor. Appl. Genet. 112:674-687.

Rehmany, A. P., Gordon, A., Rose, L. E., Allen, R. L., Armstrong, M. R. Whisson, S. C., Kamoun, S., Tyler, B. M., Birch, P. R. J., and Beynon, J. L. 2005. Differential recognition of highly divergent downy mildew avirulence gene alleles by RPP1 resistance genes from two Arabidopsis lines. Plant Cell 17:1839-1850.

Rose, L. E., Bittner-Eddy, P. D., Langley, C. H., Holub, E. B., Michelmore, R. W., and Beynon, J. L. 2004. The maintenance of extreme amino acid diversity at the disease resistance gene, RPP13, in Arabidopsis thaliana. Genetics 166:1517-1527.

Rouppe van der Voort, J., Kanyuka, K., van der Vossen, E., Bendahmane, A., Mooijman, P., Klein-Lankhorst, R., Stiekema, W., Baulcombe, D., and 
Bakker, J. 1999. Tight physical linkage of the nematode resistance gene Gpa2 and the virus resistance gene $R x$ on a single segment introgressed from the wild species Solanum tuberosum subsp. andigena CPC 1673 into cultivated potato. Mol. Plant-Microbe Interact. 12:197-206.

Sambrook, J., Fritsch, E. F., Maniatis, T. 1989. Molecular Cloning: A Laboratory Manual, 2nd ed. Cold Spring Harbor Laboratory Press, Cold Spring Harbor, NY, U.S.A.

Sandbrink, J. M., Colon, L. T., Wolters, P. J. C. C., and Stiekema, W. J. 2000. Two related genotypes of Solanum microdontum carry different segregating alleles for field resistance to Phytophthora infestans. Mol. Breed. 6:215-225.

Schaart, J. G., Krens, F. A., Pelgrom, K. T. B., Mendes Odette , and Rouwendal, G. J. A. 2004. Effective production of marker-free transgenic strawberry plants using inducible site-specific recombination and a bifunctional selectable marker gene. Plant Biotechnol. J. 2:233-240.

Schouten, H. J., and Jacobsen, E. 2008. Cisgenesis and intragenesis, sisters in innovative plant breeding. Trends Plant Sci. 13:260-261.

Shan, W. X., Cao, M., Leung, D., and Tyler, B. M. 2004. The Avrlb locus of Phytophthora sojae encodes an elicitor and a regulator required for avirulence on soybean plants carrying resistance gene Rps $1 b$. Mol. Plant-Microbe Interact. 17:394-403.

Simko, I. 2002. Comparative analysis of quantitative trait loci for foliage resistance to Phytophthora infestans in tuber-bearing Solanum species. Am. J. Potato Res. 79:125-132.

Sliwka, J., Jakuczun, H., Lebecka, R., Marczewski, W., Gebhardt, C., and Zimnoch Guzowska, E. 2006. The novel, major locus Rpi-phul for late blight resistance maps to potato chromosome IX and is not correlated with long vegetation period. Theor. Appl. Genet. 113:685-695.

Smilde, W. D., and Brigneti 2005. Solanum mochiquense chromosome IX carries a novel late blight resistance gene Rpi-moc1. Theor. Appl. Genet. 110:252-258.

Song, J., Bradeen, J. M., Naess, S. K., Raasch, J. A., Wielgus, S. M., Haberlach, G. T., Liu, J., Kuang, H., Austin-Phillips, S., Buell, C. R., Helgeson, J. P., and Jiang, J. 2003. Gene RB cloned from Solanum bulbocastanum confers broad spectrum resistance to potato late blight. Proc. Natl. Acad. Sci. U.S.A. 100:9128-33.

Tan, M. Y. A., Hutten, R. C. B., Celis, C., Park, T.-H., Niks, R. E., Visser, R. G. F., and van Eck, H. J. 2008. The RPi-mcdl locus from Solanum microdontum involved in resistance to Phytophthora infestans, causing a delay in infection, maps on potato chromosome 4 in a cluster of NBSLRR genes. Mol. Plant-Microbe Interact. 21:909-918.

Thompson, J. D., Gibson, T. J., Plewniak, F., Jeanmougin, F., and Higgins,

D. G. 1997. The ClustalX windows interface: Flexible strategies for multiple sequence alignment aided by quality analysis tools. Nucleic Acids Res. 25:4876-4882.

Toxopeus, H. J. 1964. Treasure-digging for blight resistance in potatoes. Euphytica 13:206-222.

Untergasser, A. 2006a. Cloning-Multiple Gateway Reaction II without a Mastermix. Untergasser's Lab. Published online.

Untergasser, A. 2006b. Cloning-Gateway BP-Reaction II. Untergasser's Lab. Published online.

van der Biezen, E. A., and Jones, J. D. 1998. The NB-ARC domain: A novel signalling motif shared by plant resistance gene products and regulators of cell death in animals. Curr. Biol. 8:R226-7.

van der Fits, L., Deakin, E. A., Hoge, J. H. C., and Memelink, J. 2000. The ternary transformation system: Constitutive virG on a compatible plasmid dramatically increases Agrobacterium-mediated plant transformation. Plant Mol. Biol. 43:495-502.

Van der Hoeven, R., Ronning, C., Giovannoni, J., Martin, G., and Tanksley, S. 2002. Deductions about the number, organization, and evolution of genes in the tomato genome based on analysis of a large expressed sequence tag collection and selective genomic sequencing. Plant Cell 14:1441-1456.

van der Lee, T., De Witte, I., Drenth, A., Alfonso, C., and Govers, F. 1997. AFLP linkage map of the oomycete Phytophthora infestans. Fungal Genet. Biol. 21:278-291.

van der Vossen, E., Sikkema, A., Hekkert, B. L., Gros, J., Stevens, P., Muskens, M., Wouters, D., Pereira, A., Stiekema, W., and Allefs, S. 2003. An ancient R gene from the wild potato species Solanum bulbocastanum confers broad-spectrum resistance to Phytophthora infestans in cultivated potato and tomato. Plant J. 36:867-82.

van der Vossen, E. A. G., Gros, J., Sikkema, A., Muskens, M., Wouters, D., Wolters, P., Pereira, A., and Allefs, S. 2005. The Rpi-blb2 gene from Solanum bulbocastanum is an $\mathrm{Mi}-1$ gene homolog conferring broad-spectrum late blight resistance in potato. Plant J. 44:208-222.

van Engelen, F. A., Molthoff, J. W., Conner, A. J., Nap, J.-P., Pereira, A., and Stiekema, W. J. 1995. pBINPLUS: An improved plant transformation vector based on pBIN19. Transgenic Res. 4:288-290.

Visker, M., Keizer, L. C. P., Budding, D. J., Van Loon, L. C., Colon, L. T., and Struik, P. C. 2003. Leaf position prevails over plant age and leaf age in reflecting resistance to late blight in potato. Phytopathology 93:666-674.

Vleeshouwers, V. G. A. A., van Dooijeweert, W., Keizer, L. C. P., Sijpkes, L., Govers, F., and Colon, L. T. 1999. A laboratory assay for Phytoph thora infestans resistance in various Solanum species reflects the field situation. Eur. J. Plant Pathol. 105:241-250.

Vleeshouwers, V. G. A. A., Rietman, H., Krenek, P., Champouret, N. Young, C., Oh, S.-K., Wang, M., Bouwmeester, K., Vosman, B., Visser, R. G. F., Jacobsen, E., Govers, F., Kamoun, S., and Vossen, E. A. G. V. d. 2008. Effector genomics accelerates discovery and functional profiling of potato disease resistance and Phytophthora infestans avirulence genes. PLoS ONE 3 (8):e2875.

Whisson, S. C., van der Lee, T., Bryan, G. J., Waugh, R., Govers, F., and Birch, P. R. J. 2001. Physical mapping across an avirulence locus of Phytophthora infestans using a highly representative, large-insert bacterial artificial chromosome library. Mol. Genet. Genomics 266:289-295.

Whisson, S. C., Boevink, P. C., Moleleki, L., Avrova, A. O., Morales, J. G., Gilroy, E. M., Armstrong, M. R., Grouffaud, S., van West, P., Chapman, S., Hein, I., Toth, I. K., Pritchard, L., and Birch, P. R. J. 2007. A translocation signal for delivery of oomycete effector proteins into host plant cells. Nature 450:115-118.

Yu, W., Lamb, J. C., Han, F., and Birchler, J. A. 2006. Telomere-mediated chromosomal truncation in maize. Proc. Natl. Acad. Sci. U.S.A. 103:17331-17336. 